\title{
Twenty-Five Years and Still Counting
}

\author{
By Gary Frasier
}

This is the sixth issue of our celebration of the $25^{\text {th }}$ Anniversary of Rangelands. It has been an exhilarating year.

We have reprinted several articles from the issues of 25 years ago. We tried to place a perspective on maybe how the Society for Range Management was meeting its goals and objectives, both current as well as those from 25 years ago. We have had articles and comments from many of the past Society for Range Management Presidents with their thoughts as to how they perceive that we have met the challenges of 25 years ago and how we are meeting the new challenges of today.

There have been great articles comparing what the rangelands looked like 25 years ago and what it looks like now. We have had articles expressing thoughts as to the problems facing the Society for Range Management with respect to their publications.

What have we learned? We have made progress in some areas. The one thought that has been consistent in the review of the past 25 years is that we are making progress in improving the rangeland resource, whether it be for livestock, wildlife, or the public. There are other areas where we, as a range oriented society, are still facing the problems that were identified 25 years ago.There are also new concerns that were not present 25 years ago.

Shortly after you receive this issue of Rangelands we will be attending the $57^{\text {th }}$ Annual Meeting of the Society for Range Management. The theme of this meeting is "Rangelands In Transition." Several of the papers from the Plenary Session are printed in this issue of Rangelands. These papers fit in very well with what we have been trying to accomplish with these Anniversary issues of Rangelands.

Where do we go from here? We can not stop. We have not reached the end of telling the many stories of rangeland resource management. We have many dedicated people out there who are spending a lifetime insuring that our natural resources are left in a better condition than when they started working.
We have had some great leaders in the Society for Range Management. Some were on the SRM Board of Directors. Others have labored hard behind the scenes. We want to tell their stories. We will continue to look back to the past with an eye to the future. This is our measure of progress.

Many of the people who have shaped our future of the past 25 years are retired. They will not be forgotten. The efforts of these people are being continued by a new group of individuals who have the same vision as was expressed in the first issues of Rangelands.

What has Rangelands accomplished in the past 25 years? It has provided a means of keeping all readers informed in a non-technical manner, of ideas and means for managing the rangelands. I have been very privileged to be a part of the Rangelands effort. Since 1984 when I assumed the editor's duties I have worked with some outstanding authors. The Editorial staff of Rangelands, Kindra Gordon, managing editor and Patty Rich, production editor, are very dedicated to producing the "best." This will be continued in the future. We have had great support from the SRM Board of Directors and all the SRM staff in Lakewood. I look forward to the next 25 years of Rangelands. It should be great reading.

\begin{tabular}{|c|c|c|}
\hline \multicolumn{3}{|c|}{$\begin{array}{l}\text { Drought Tolerant Forage } \\
\text { Firebreaks/Greenstripping } \\
\text { Weed Suppression } \\
\text { Habitat }\end{array}$} \\
\hline & \multicolumn{2}{|c|}{ wWw.kochiaseed.com } \\
\hline \multicolumn{3}{|c|}{$\begin{array}{l}\text { Immigrant Forage Kochia (Kochia prostrata), a problem solving plant } \\
\text { with no par }\end{array}$} \\
\hline telephone: & fax: & mail: \\
\hline Gene 509-982-2288 & $\begin{array}{l}509-982-2220 \\
\text { e-mail: }\end{array}$ & $\begin{array}{l}8588 \text { Rd. U, } \\
\text { Marlin, WA }\end{array}$ \\
\hline Greg 509-765-7946 & \multicolumn{2}{|c|}{ information@kochiaseed.com } \\
\hline
\end{tabular}

